\title{
Development of an Evaluation Method for the Pore Structure of Sinter Cake and Its Application to the Permeability Analysis
}

Shunji KaSAma, Tadahiro INAZUMI and Tsutomu NAKAYASU

Synopsis :

Pore structure of sinter cake was observed three-dimensional with high energy $\mathrm{X}$-ray computerized tomography. Most of pores of $5 \mathrm{~mm}$ or more in two-dimensional size were three-dimensional stem pores composing a complicated network linked with each other.

A new analysis method employing the $\mathrm{X}$-ray computerized tomography has been developed for evaluating the sinter cake pore structure, based on a network model. This method has successfully made it possible to quantify the complexities of the pore network and pore thickness.

Applying this method to the analysis of the sinter cakes having the different permeability, importance of pore branch structure for the permeability was elucidated. Promoting the coalescence of iron ore particles securing stem pores improves the permeabilty of sinter cake because of producing a permeable pore network.

Key words : iron ore sintering; X-ray computerized tomography; three-dimensional image ; analysis of sinter cake; pore structure; network model; evaluation of permeability.

\section{1. 緒}

焼結プロセスの通気の重要性については従来から多く の研究がなされており1), マクロには Ergun 式で評価で きることが知られている ${ }^{2) 3)}$ ，しかしながら，溶融帯や シンターケーキはきわめて複雑な形状の多孔体であるた め Ergun 式の適応性は十分ではない4). したがって焼結 ベッドの通気性を正確に評価するためには気孔構造の解 明が重要な課題である.

またシンターケーキの気孔構造は焼結ベッドの通気性 に影響を及ぼすだけでなく，焼結時の燃焼帯へ空気を分 配する流路として焼結反応にも間接的に影響を及ぼしう る. 焼けむらなどの不均一な燃焼帯の降下現象を解明す るためには，シンターケーキ内のガス流れ分布を理解す ることが重要であり，そのためにも気孔構造の定量化が 必要である.

平成 3 年 11 月 7 日受付 平成 4 年 4 月 10 日受理（Received on Nov. 7, 1991; Accepted on Apr. 10, 1992)

* 新日本製鉄(株)プロセス技術研究所 (Process Technology Research Laboratories, Nippon Steel Corp., 20-1 Shintomi Futtsu 299-12)

*2 新日本製鉄(株)プロセス技術研究所 工博 (Process Technology Research Laboratories, Nippon Steel Corp.)

*3 新日本製鉄(株)君津製鉄所 (Kimitsu Works, Nippon Steel Corp.)
本報告では実態に即した気孔構造評価法の開発とその 通気性解明への応用を目的として，ネットワークモデ $ル^{5)}$ の概念を導入した気孔形態の解析法 (ネットワーク 解析）を開発した.このネットワーク解析を適用して実 機および焼結鍋で得られた代表的なシンターケーキの気 孔構造解析を行い, 通気性との関係について考察した。

\section{2. シンターケーキ気孔構造の定量化法の開発}

\section{$2 \cdot 1 \mathrm{X}$ 線断層撮影}

シンターケーキの断層撮影には, 田ロら ${ }^{5)}$ が開発した 高エネルギー X 線断層撮影装置 (CT と略す)を用いた. この CTは $420 \mathrm{kV}$ の X 線管を使用しており, 鉄鉱石 のような高密度の物体を $0.25 \mathrm{~mm}$ の分解能で断層撮影 できる6).

CT 解析用のシンターケーキは開気孔部にパラフィン を注入して固化させ，一辺が $40 \mathrm{~mm}$ の立方体ブロック 
に切断分割したのち， CT によってブロックの中心部の 垂直断面を撮影した。

\section{$2 \cdot 2$ シンターケーキ内の気孔径分布}

気孔構造の特徴を理解するために, CT 画像よりシン ターケーキ中の気孔径分布を計測した。その結果を Fig. 1 に示す。この結果より, 気孔率と気孔径の間に は明確な相関が認められる。すなわち，全気孔率の高い 箇所では $5 \mathrm{~mm}$ 以上の粗大気孔（+5 $\mathrm{mm}$ 気孔）の構成 比率が高く，逆に気孔率の低い箇所では $5 \mathrm{~mm}$ 以下の気 孔（-5 mm 気孔）の構成比率が高い.

このような気孔径分布の法則性から， $5 \mathrm{~mm}$ 近傍を境 にして気孔の形態が全く異なることが予想された.この 点を解明するためにシンターケーキ内の気孔構造を 3 次 元的に観察した。

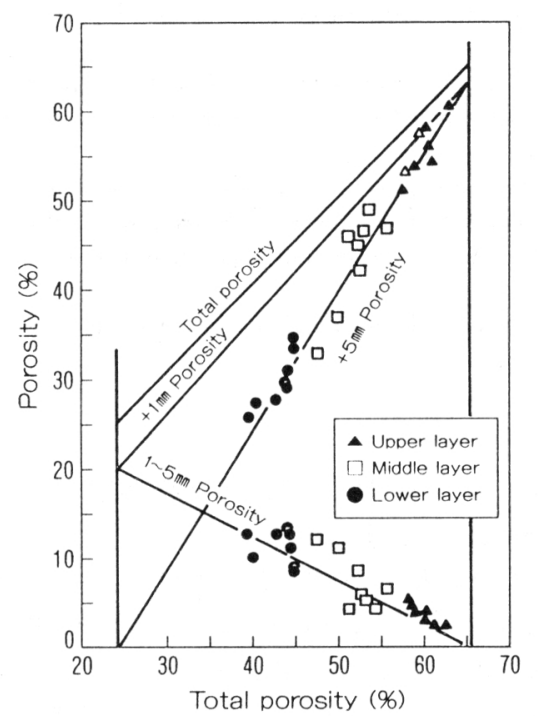

Fig. 1. Relationship between total porosity and porosity classified by pore size.

\section{$2 \cdot 3$ 気孔の 3 次元構造の観察}

シンターケーキ内の気孔の実態を理解するために，同 一試料の水平断面を $1 \mathrm{~mm}$ 間隔で連続的に断層撮影し,

計算機処理によって Photo. 1 に示すような 3 次元画像 を再構成した。

この方法により，2 次元断面だけでは把握しにくい気 孔の 3 次元的な形態や気孔どうしの連結性などを容易に 判定できる，その結果， 2 次元画像上の $-5 \mathrm{~mm}$ 気孔は 球状の閉気孔であるのに対し， $+5 \mathrm{~mm}$ 気孔のほとんと は 3 次元的に相互に連結した貫通気孔を形成しているこ とがわかった。

この貫通気孔はきわめて複雑なネットワークを構成し ており，真円度などの形状評価指数ではその形態を十分 には定量化できない。このような貫通気孔の分岐形態を うまく定量化するために, Dullien が提案しているネッ トワークモデル7)の考え方を導入し, 次節に述べる新し い画像解析法を開発した。

\section{$2 \cdot 4$ 気孔の分岐形態の定量化法 (ネットワーク解析)}

気孔のネットワーク解析の手順を Fig. 2 に示す。ま

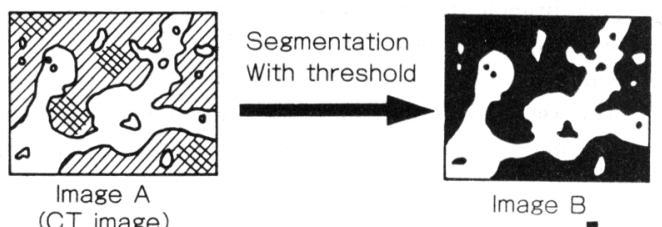

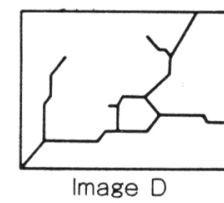
(network image)

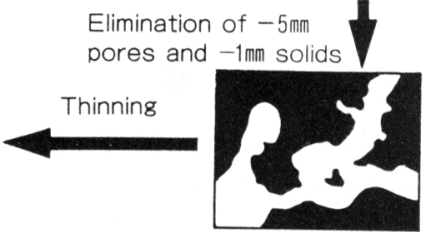

Image $\mathrm{C}$

Fig. 2. The image processing sequence of "network analysis".
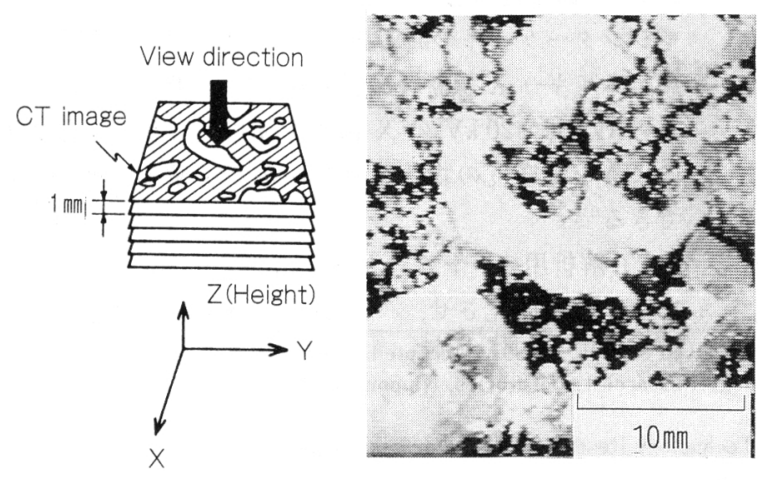

Photo. 1. Three-dimensional pore image composed of six CT images (Pores are described in white. Solids are described transparentry). 
ず 512 階調のグレイレベルで表示される CT 画像を 2 值化し気孔を抽出した。このとき， $-5 \mathrm{~mm}$ 気孔は固体 組織の一部とみなし画像より取り除いた。また, 画像上 のノイズを除去するために，1 $\mathrm{mm}$ 以下の固体粒子を取 り除いた。次に，細線化処理によって全画像が線分（1 画素幅）に到達するまで収縮操作を繰り返した。この処 理によって生成した線画像を気孔のネットワークと定義 し，その形態を( 1 )式および( 2 )式に示したブランチ密 度 $D_{b}$ とブランチ幅 $W_{b}$ の 2 つの指数で表すこととし た.

ブランチ密度 $D_{b}$ はネットワークを構成する個々の線 分の本数 (Fig. 2 の例では 12 本となる) 密度に相当し, 分岐の複雑さを表す指数である. ブランチ幅 $W_{b}$ は線分 と直角方向の気孔の平均的な太さを表す指数であり，気 孔の面積 $A_{p}$ をネットワークの全長 $L_{b t}$ でわることによ り求められる.

$$
\begin{aligned}
& D_{b}=N_{b} / A_{f} \\
& W_{b}=A_{p} / L_{b t}
\end{aligned}
$$

\section{3. サンプルおよび実験方法}

ネットワーク解析の応用例として, 以下に示す 3 種類 のシンターケーキを調製し，気孔分岐構造を解析した。

\section{$3 \cdot 1$ 実機焼結機のシンターケーキサンプリング}

実機の代表サンプルとして，八幡製鉄所若松焼結機で 微粉鉱石の多量配合試験を実施したときのシンターケー キを採取した ${ }^{8)}$. 後述すると扔り，この試料は未焼結部 から過溶融部に至るまでの多様な構造を有しており，気 孔構造のキャラクタリゼーションに最適と思われた。な お，この試験中の操業成績は，通常操業に比べ歩留が約 $2 \%$ も低い状態であった。

\section{$3 \cdot 2$ 通気性の異なるシンターケーキの作製}

通気性の異なる代表的なシンターケーキを作製するた めに，以下の 2 種類の鍋試験を行った。それぞれの試験 条件を Table 1 に示す.

$3 \cdot 2 \cdot 1$ 原料充填構造の変更試験

当社の平均的な配合原料を用い，直径 $0.3 \mathrm{~m}$ の鍋で
約 $60 \mathrm{~kg}$ の原料を焼成した. CASE-A のベース条件に 対して, 装入時の落差の低減 (CASE-B), 生石疢の添 加 (CASE-C) および原料の粗粒化 (CASE-D) の 3 万法で原料層の通気性を变えた鍋試験を実施した。

それぞれの実験条件に対して 2 本のシンターケーキを 焼成した。 1 本目はシャッター試験機を使って $2 \mathrm{~m} の$ 高さから 5 回の落下破砕を行い，歩留や強度などの一般 的な焼結特性を測定した。2 本目の焼成実験においては 焼成前の原料層と焼成後のシンターケーキについて通気 度の評価を行ったのち，CT 解析に供した。通気度の評 価はガスの空塔速度を $1.5 \mathrm{~m} / \mathrm{s}$ 以下の範囲で変えたと きの圧力損失を測定した.

$3 \cdot 2 \cdot 2$ アルミナ配合率の変更試験

最近の川口らの報告9) では，原料中のアルミナの配合 率がシンターケーキ構造にきわめて大きな影響を及ぼす ことが明らかにされている。ここではアルミナ配合率が $1 \%$ と $4 \%$ のシンターケーキを焼成し, 前項と同じ方法

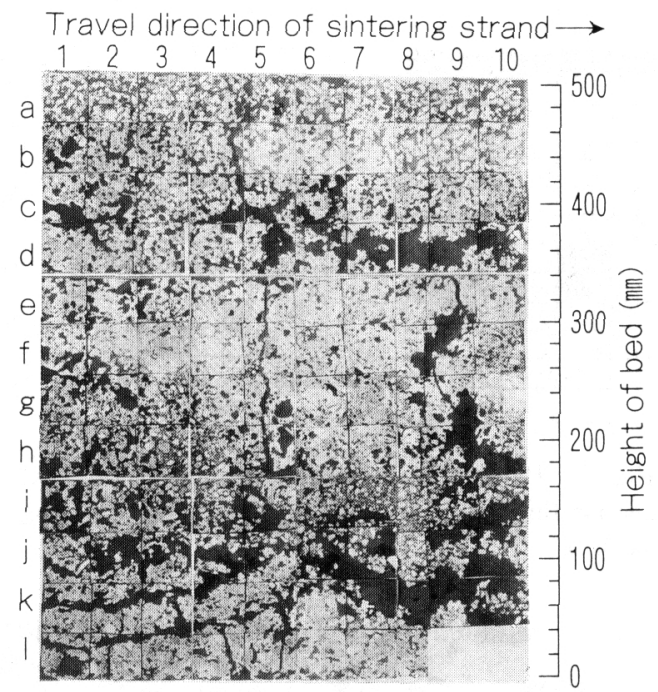

Photo. 2. CT image of londitudinal section through sinter cake on Wakamatsu sintering machine.

\begin{tabular}{|c|c|c|c|c|c|c|}
\hline Items & CASE-A & CASE-B & CASE-C & CASE-D & Low $\mathrm{Al}_{2} \mathrm{O}_{3}$ & High $\mathrm{Al}_{2} \mathrm{O}_{3}$ \\
\hline $\begin{array}{l}\mathrm{SiO}_{2}(\% \text { in mix }) \\
\mathrm{Al}_{2} \mathrm{O}_{3}(\% \text { in mix }) \\
\mathrm{C} / \mathrm{S}(-) \\
\text { Mean size }(\mathrm{mm}) \\
\text { Quicklime }(\%) \\
\text { Coke }(\%)\end{array}$ & $\begin{array}{l}5.09 \\
1.72 \\
1.61 \\
1.75 \\
- \\
3.5\end{array}$ & $\begin{array}{l}5.09 \\
1.72 \\
1.61 \\
1.76 \\
- \\
3.5\end{array}$ & $\begin{array}{l}4.99 \\
1.69 \\
1.99 \\
1.87 \\
2.0 \\
3.5\end{array}$ & $\begin{array}{l}4.88 \\
1.73 \\
1.67 \\
2.08 \\
- \\
3.5\end{array}$ & $\begin{array}{l}5.2 \\
1.25 \\
1.72 \\
1.76 \\
3.0 \\
4.0\end{array}$ & $\begin{array}{l}5.2 \\
4.00 \\
1.72 \\
1.65 \\
3.0 \\
4.0\end{array}$ \\
\hline $\begin{array}{l}\text { Drop height of mix }(\mathrm{m}) \\
\text { Bed height }(\mathrm{m}) \\
\text { Suction pressure }(\mathrm{kPa})\end{array}$ & $\begin{array}{r}1.8 \\
0.5 \\
12.7\end{array}$ & $\begin{array}{r}0.6 \\
0.5 \\
12.7\end{array}$ & $\begin{array}{r}1.8 \\
0.5 \\
12.7\end{array}$ & $\begin{array}{r}1.8 \\
0.5 \\
12.7\end{array}$ & $\begin{array}{l}0.6 \\
0.5 \\
9.8\end{array}$ & $\begin{array}{l}0.6 \\
0.5 \\
9.8\end{array}$ \\
\hline
\end{tabular}

Table 1. Experimental conditions of the sinter pot tests. 
で通気度測定および CT 解析を行った。

\section{4. 結言}

\section{$4 \cdot 1$ 気孔の分岐構造のキャラクタリゼーション}

実機シンターケーキの CT 画像を Photo. 2 に示す. 画像からわかると抢り,このシンターケーキの特徴は中 層部に気孔率の低い過溶融部が発達し通気阻害によって その直下に未焼結部が残留している点にある。

$40 \mathrm{~mm} \times 40 \mathrm{~mm}$ の視野を単位としてシンターケーキ 内のすべての箇所について, 気孔のブランチ密度とブラ ンチ幅を計測した. 解析結果を Fig. 3 に示す.これより, 表層部などの焼結の不十分な箇所においてはブランチ密 度が高くブランチ幅が小さいことがわかる。

ブランチ密度とブランチ幅の関係を Fig. 4 に示す. ここでは横軸にブランチ密度を, 縦軸にブランチ幅をプ

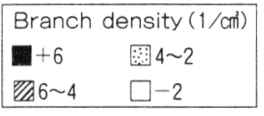

$\begin{array}{llllllllll}1 & 2 & 3 & 4 & 5 & 6 & 7 & 8 & 9 & 10\end{array}$

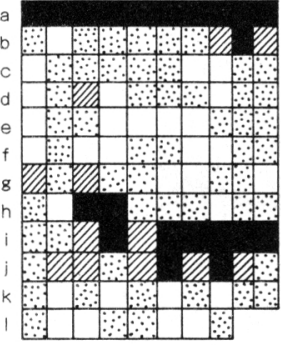

(a) Branch density
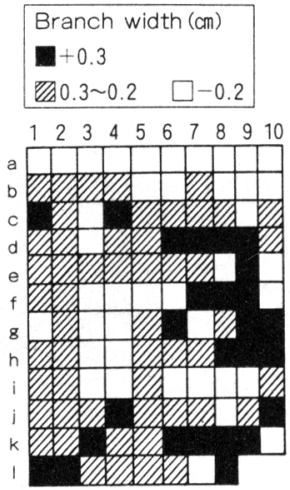

(b) Branch width

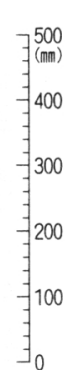

Fig. 3. Pore branch structures of longitudinal section through sinter cake on Wakamatsu sintering machine.
ロットした。このプロット上で+ $5 \mathrm{~mm}$ 気孔率とその分 岐構造指数を同時に読み取るために，(3)式で算出した $+5 \mathrm{~mm}$ 気孔率の理論值を図中に点線で示した。なお, この計算ではブランチ長さ $L_{b}$ をブランチ幅の 2.18 倍 (実測値の平均值) と仮定した.

$$
P=W_{b} \cdot L_{b} \cdot D_{b}
$$

この結果より，気孔率が同じであっても分岐形態はさま ざまであり，その形態は固体部分の焼結進行度と密接に 関連していることがわかる.Fig. 4 では固体部の構造 を既報 ${ }^{8)}$ の方法にしたがって CT 值で分類した。すなわ ち低密度固体部の比率 (CTL) が $24 \%$ 以上のものを未 焼結状態とみなし, 高密度固体部の比率 ( CTH) が $25 \%$ 以上のものを過剩焼結状態と判定した.

未焼結状態に相当する箇所はブランチ密度が高くブラ ンチ幅が小さい。これは原料粒子間の空隙部に相当する

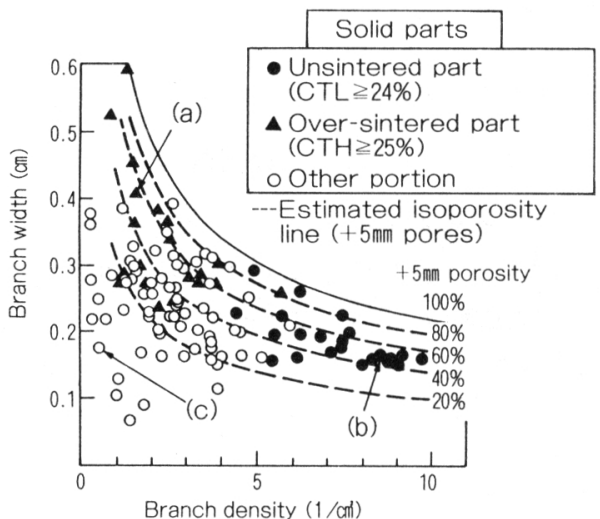

(a) Vicinity of large pores (b) Unsintered portion (c) Over-melted portion

Fig. 4. Relationship between branch density, branch width and $+5 \mathrm{~mm}$ porosity.

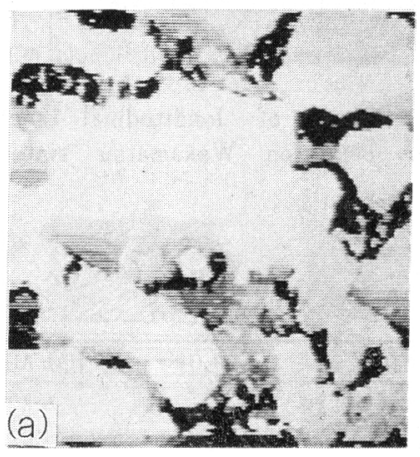

(a) Vicinity of large pores $(+5 \mathrm{~mm}$ pores $=52.6 \%)$

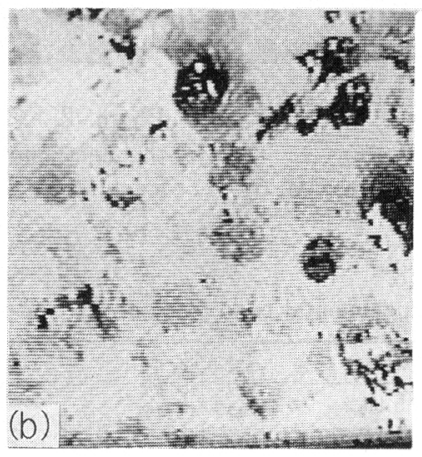

(b) Unsintered portion $(+5 \mathrm{~mm}$ pores $=49.5 \%)$

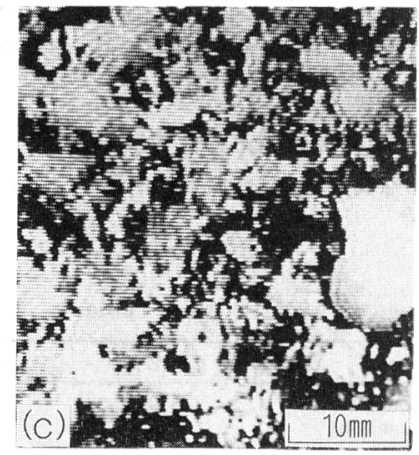

(c) Over-melted portion $(+5 \mathrm{~mm}$ pores $=5.0 \%)$

Photo. 3. Pore branch structures of sintering machine (Three-dimensional pore images (a) $\sim(\mathrm{c})$ are composed by the same method as shown in Photo. 1). 
Table 2. Experimental results of the sinter pot tests.

\begin{tabular}{|c|c|c|c|c|c|c|}
\hline Items & CASE-A & CASE-B & CASE-C & CASE-D & Low $\mathrm{Al}_{2} \mathrm{O}_{3}$ & High $\mathrm{Al}_{2} \mathrm{O}_{3}$ \\
\hline Bulk density $\left(10^{3} \mathrm{~kg} / \mathrm{m}^{3}\right)$ & 1.93 & 1.80 & 1.87 & 2.00 & 1.87 & 1.84 \\
\hline Flame front speed $(\mathrm{mm} / \mathrm{min})$ & 10.6 & 13.8 & 13.8 & 11.7 & 18.1 & 15.2 \\
\hline Product yield $(+5 \mathrm{~mm} \%)$ & 69.0 & 73.5 & 73.7 & 75.0 & 83.0 & 76.8 \\
\hline Productivity $\left(\mathrm{t} / \mathrm{h} / \mathrm{m}^{2}\right)$ & 0.86 & 1.17 & 1.11 & 1.04 & 1.57 & 1.25 \\
\hline JIS-Shatter Index $(+10 \mathrm{~mm} \%)$ & 78.3 & 78.7 & 75.7 & 83.3 & 96.2 & 91.3 \\
\hline Shrinkage of bed $(\%)$ & 4.7 & 17.2 & 5.5 & 5.7 & 12.4 & 12.9 \\
\hline
\end{tabular}

形態であり，気孔壁の薄いネット状の貫通気孔となって いる (Photo. 3(b)).

焼結の進行にともなってブランチ密度は減少しブラン チ幅が増大する傾问がみられる. Photo. 3(a)に示す過 㮃焼結部ではブランチ幅が非常に大きくなり，太い気孔 が互いに結合した連続体を形成している，ただしこの部 分では閉気孔の比率は極めて少ない。このほかに気孔率 の極めて低い簓所も存在する。ここでは貫通気孔がほと んどなく球状の形態をしたー $5 \mathrm{~mm}$ 気孔が非常に多いの が特徵である (Photo. 3(c)).これは過剩な融液生成に

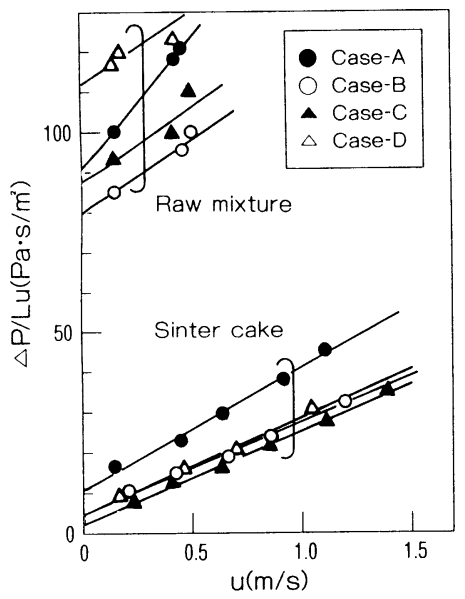

Fig. 5. Comparison of permeability of sintering bed before and after sintering.

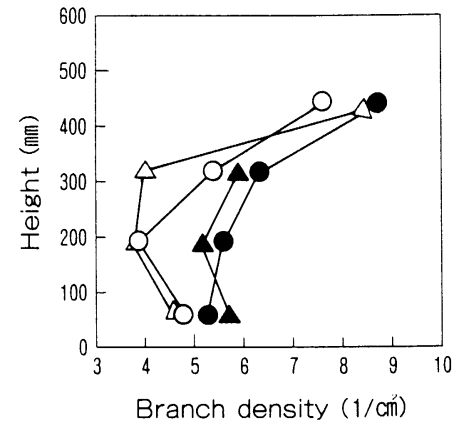

(a) Branch density
よって貫通気孔が閉塞した構造と考えられこのため下 層への通気阻害が起こりその直下に未焼結部が発生した ものと思われる。

以上のように，焼結のような鉱石の溶融同化によって 気孔が再編成される現象においては，気孔構造の特徵を 気孔率だけでなく気孔の分岐構造としてとらえることが 重要である.

\section{$4 \cdot 2$ 原料充填構造の影響}

$4 \cdot 2 \cdot 1$ 焼結性および通気性

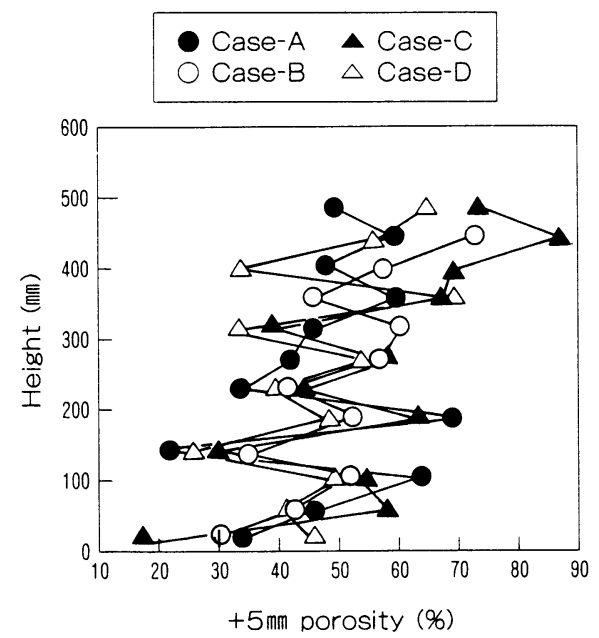

Fig. 6. Comparison of distribution of $+5 \mathrm{~mm}$ porosity in height direction.

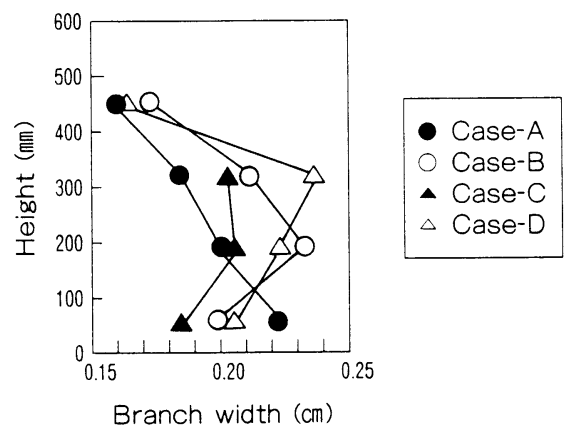

(b) Branch width

Fig. 7. Comparison of distribution of branch indices in height direction. 
焼結鍋試験の結果を Table 2 に示す．装入時の落差 の低減, 生石扊の添加および原料の粗粒化のいずれの方 法によっても焼結速度は向上した。

原料層とシンターケーキの圧損の測定結果を Fig. 5 に示す。ここでは横軸に空塔ガスを流速, 縦軸に圧力損 失をガス流速で除した指数をとって整理した。 シンター ケーキの通気性の優劣は原料層のそれと必ずしも対応し ておらず，溶融による気孔構造の変化が強く影響してい ることがわかる.

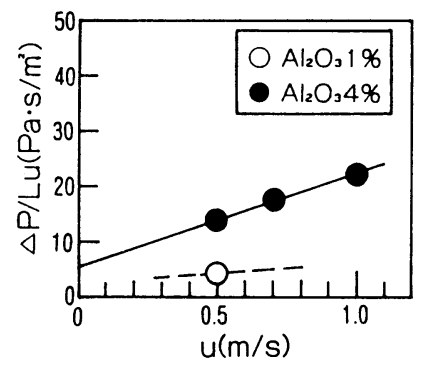

Fig. 8. Effect of the gas velocity on the pressure drop of sinter cake.

\section{$4 \cdot 2 \cdot 2$ シンターケーキの気孔構造}

$+5 \mathrm{~mm}$ 気孔率とブランチ指数の高さ方向分布を Fig. 6 およびFig. 7 に示す. 気孔率では明確な差がみられ ないが, ブランチ指数で比較すると各条件ごとに大きな 違いがみられる. CASE-A はブランチの多い複雑なネッ トワークとなっている，逆に装入密度の低いCASE-B および粗粒の CASE-D は, 気孔の統合が進んだ単純な ネットワークが構築されている.

\section{$4 \cdot 3$ アルミナ配合率の影翌}

アルミナ配合率を $1 \%$ から $4 \%$ に変えたときの通気 性と気孔構造の変化を Fig. 8 および Fig. 9 に示す.ア ルミナの影響は極めて大きく，アルミナを $3 \%$ 上げる ことによって気孔の分岐構造が著しく複雑化し圧損は約 3 倍に上昇した。

\section{5. 考察}

\section{$5 \cdot 1$ 気孔の分岐形態と通気性の関係}

シンターケーキ内の気孔が複雑なネットワークである ことから，その中のガス流れも極めて複雑であると推測 される.ここでは, 気孔構造と通気性の関係を解析し,

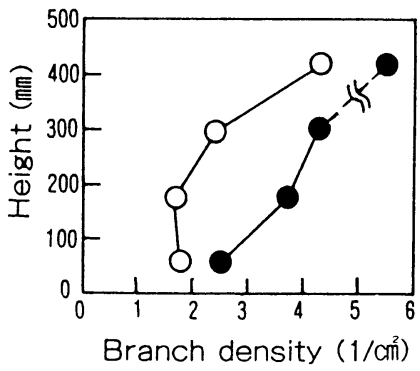

Branch density $\left(1 / \mathrm{cm}^{2}\right)$

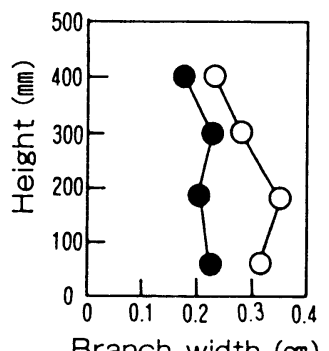

Branch width (cm)
$\mathrm{Al}_{2} \mathrm{O}_{3} 1 \%$

$\mathrm{Al}_{2} \mathrm{O}_{3} 4 \%$
Fig. 9. Comparison of distribution of branch indices in height direction.

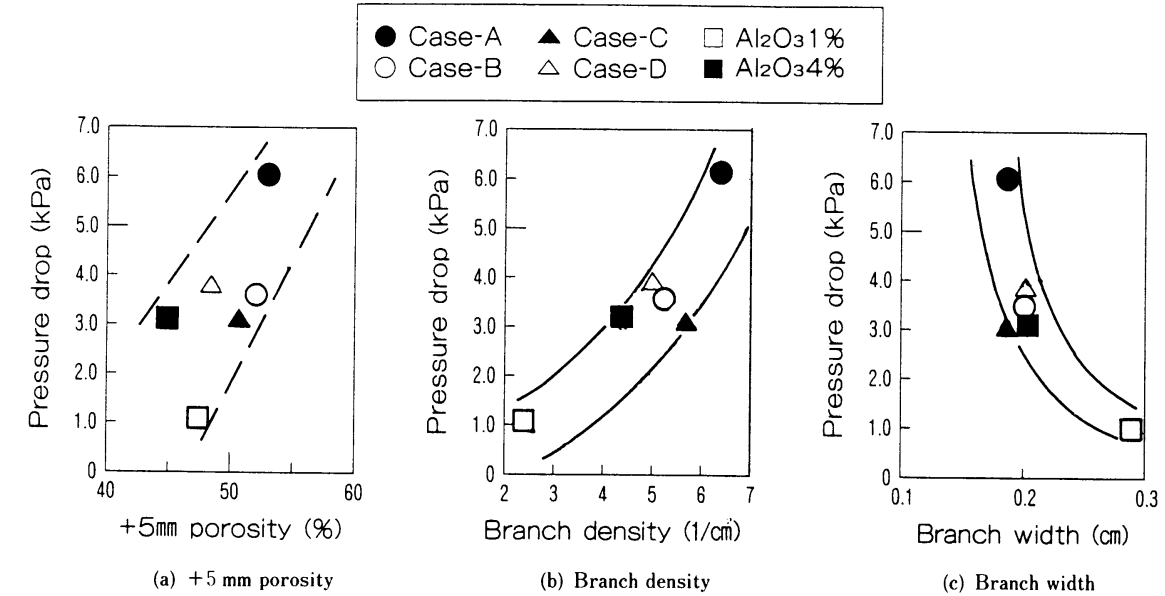

Fig. 10. Relationship between total pressure drops and pore branch structures in sinter cake (gas velocity is $0.5 \mathrm{~m} / \mathrm{s}$ ). 
通気にとっての最適気孔構造について考察した。

$0.5 \mathrm{~m} / \mathrm{s}$ の一定ガス流速下におけるシンターケーキの 圧損と気孔構造との関係を Fig. 10 に示す. $+5 \mathrm{~mm}$ 気 孔率を見ると気孔率が高いほど通気性が悪いという結果 になっており，今回の実験結果は一般常識と明らかに矛 盾する. 一方，ブランチ指数はシンターケーキの圧損と 良い相関を示しており，気孔のネットワークが単純化す るほどシンターケーキの通気性は向上する，すなわち鉱 石の溶融同化によって気孔の合体統合が進むほど，ガス の流路が広がり通気抵抗は減少する．したがって焼結 ベッドの通気性を改善させる 1 つの手段として，溶融反 応を促進させ単純なガス流路を造り込むことが有効と考 えられる。

\section{$5 \cdot 2$ シンターケーキ内のガス流れ}

気孔構造の単純化により通気性が改善するメカニズム を考察するために， Ergun 式を使ってマクロなガス流 れ状態を検討した. Fig. 5 のプロットの切片と傾きよ $\eta(5)$ 式および $(6)$ 式の抵抗係数 $a$ および $b$ を求め, ガス流速を $0.5 \mathrm{~m} / \mathrm{s}$ と仮定したときの(4)式の各項の 大きさを計算した

$\Delta P / L=a \cdot \eta \cdot u+b \cdot \rho \cdot u^{2}$

ここで

$$
\begin{aligned}
& a=150 \cdot \frac{(1-\varepsilon)^{2}}{d p^{2} \cdot \varepsilon^{3}} \\
& b=1.75 \cdot \frac{(1-\varepsilon)}{d p \cdot \varepsilon^{3}}
\end{aligned}
$$

計算結果を Table 3 に示す。この結果によれば層流 抵抗よりも乱流抵抗の寄与が相対的に大きく，シンター ケーキの通気性に対しては固体表面での流体摩擦という よりも，むしろガス流路の分岐・合流や拡大・縮小にとも なう圧力損失が大きく影響していると考えられる，葛西 ら4)も指摘しているように, Ergun 式ではこのような現 象が考慮されていないため, 気孔径 $d_{p}$ を実質上の フィッティングパラメータとして取り扱わざるをえな い.

シンターケーキのような不定形多孔体の通気性を正し く評価するためには, 従来の Ergun 式では不十分であ り，ネットワークモデルの考え方に基づいてガス流路の 本数, 太さおよびそれらの連結性を考慮できるガス流れ
モデルを開発していく必要がある。

\section{$5 \cdot 3$ 通気性からみたシンターケーキの最適気孔構造}

シンターケーキの気孔分岐構造を表すマップ上にシン ターケーキの圧損值をプロットして Fig. 11 に示す。こ のマップの通気性の最適範囲は等気孔率線に沿って左上 へと向かった方向に位置する.この変化は原料の溶融を 促進させる方向と一致するもので，通気改善のためには 十分に溶融同化を進めブランチ幅の広い気孔ネットワー クを造り込むことがのぞましい．

また実機のシンターケーキの解析結果では，過溶融に よって気孔率の著しく低い箇所が形成した場合には下層 へのガスの供給が阻害され下層での焼結反応に悪影響を 及ほすことが確かめられた。このような気孔条件はマッ プ上の左下の気孔率の低い範囲に相当する。これを避け るためには溶融を進めつつも必要最小限の貫通気孔を維 持することが重要である.

以上の知見から，シンターケーキの通気性にとって最 適な気孔構造は Fig. 12 に示した範囲内に存在する。こ のシンターケーキの最適気孔構造は, 単に焼結完了層の 通気だけでなく，同様の物理構造を持つ溶融帯について も大きく影響すると考えられ，焼結ベッド全体の通気性 に対してもその影響は無視できない. 最適な気孔構造を 造り込むためには，焼結べッドの高さ方向での投入熱

- Case-A A Case-C $\square \mathrm{Al}_{2} \mathrm{O}_{3} 1 \%$ $\mathrm{O}$ Case-B $\triangle$ Case-D $-\mathrm{Al}_{2} \mathrm{O}_{3} 4 \%$

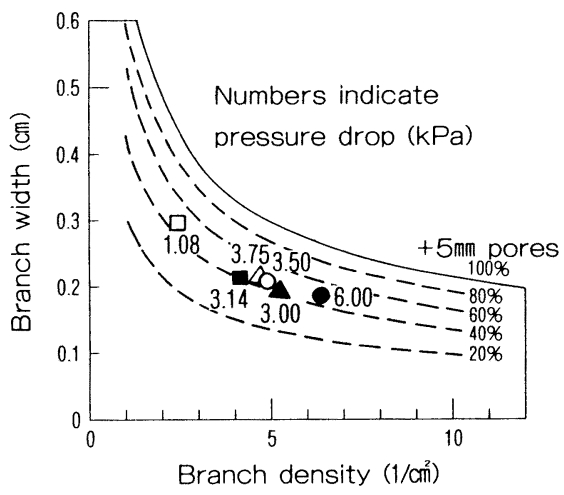

Fig. 11. Relationship between total pressure drops and pore branch structures.

Table 3. Comparison between viscous resistance and inertial resistance at a constant gas velocity $(u=0.5$ $\mathrm{m} / \mathrm{s}$ ) in sinter cake.

\begin{tabular}{c|ccccc}
\hline Terms & CASE-A & CASE-B & CASE-C & $\mathrm{CASE}^{-\mathrm{D}}$ & $\mathrm{Al}_{2} \mathrm{O}_{3} 1 \%$ \\
\hline Pressure drop $: \Delta P / L(\mathrm{kPa} / \mathrm{m})$ & 12.0 & 7.0 & 6.0 & 7.5 & 2.2 \\
Viscous $: \boldsymbol{a} \cdot \boldsymbol{\eta} \cdot \boldsymbol{u}(\mathrm{kPa} / \mathrm{m})$ & 4.8 & 1.8 & 0.8 & 2.0 & No data \\
Inertial $: \boldsymbol{b} \cdot \boldsymbol{\rho} \cdot \boldsymbol{u}^{2}(\mathrm{kPa} / \mathrm{m})$ & 7.2 & 5.2 & 5.2 & 5.5 & No data \\
\hline
\end{tabular}




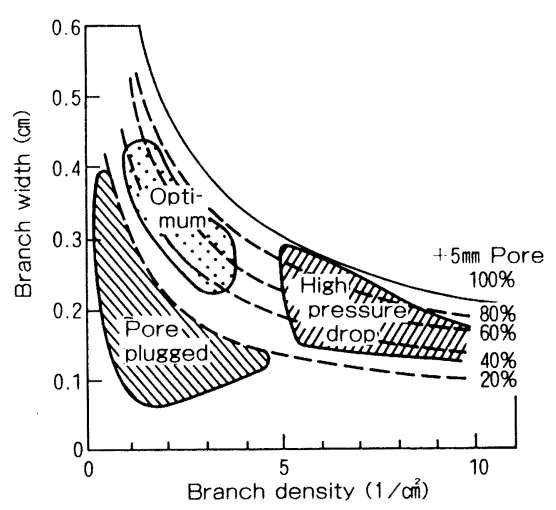

Fig. 12. Classification of pore branch structure by the indices of network analysis.

量，原料粒度および成分などを適正に制御する技術を開 発することが今後の重要な課題となると考えられる.

また，鉱物組織や微細気孔などの固体部の構造 ${ }^{8)}$ まで 考慮した場合には, Fig. 12 の最適気孔構造の生成条件 は必ずしも適正な焼成条件とは言えない，画者の最適条 件を同時に満たせる制御技術を開発するためには，焼結 の溶融同化過程における形態変化を詳細に解析していく 必要がある.

\section{6. 結言}

$\mathrm{X}$ 線 CTを用いたシンターケーキの気孔構造の解析 により，+5 mm 気孔は相互に連結した貫通気孔であり， 複雑なネットワークが形成されていることを確認した。

複雑な気孔分岐構造の新しい解析法として, ネット ワークモデルの概念を導入した形態解析法を開発した.

これにより不定形連続体である気孔のネットワークの複 雑さやガス流路の太さを等量的に評価することが可能と なった。

この解析法をシンターケーキの通気性評価に応用した
結果，通気性の支配要因として気孔率だけでなく気孔の 分岐構造が重要であることがわかった，通気性を改善す るためには，鉱石の合体統合を促進させることでガスの 流路となる気孔のネットワークも単純化し，小ブランチ の少ない気孔ネットワークを造り込むことが望ましい.

おわりに CT 画像の 3 次元構成に御協力いただいた (株)富士通研究所白石 博氏, 柿本正憲氏および稲野 聡氏に感謝の意を表します。

\section{記 号}

$D_{b}:$ ブランチ密度 $\left(1 / \mathrm{cm}^{2}\right)$

$A_{f}:$ 視野面積 $\left(\mathrm{cm}^{2}\right)$

$W_{b}:$ ブランチ幅 $(\mathrm{cm})$

$A_{p}$ : 気孔の面積 $\left(\mathrm{cm}^{2}\right)$

$N_{b}:$ ブランチの本数 $($ - $)$

$L_{b t}$ : 視野内のブランチの全長 $(\mathrm{cm})$

$\Delta P:$ 焼結べッドの圧力損失 $(\mathrm{Pa})$

$L$ : 層高 $(\mathrm{m})$

$u:$ 空塔ガス流速 $(\mathrm{m} / \mathrm{s})$

$\rho:$ ガス密度 $\left(\mathrm{kg} / \mathrm{m}^{3}\right)$

$\eta$ : ガスの粘度 $(\mathrm{Pa} \cdot \mathrm{s})$

$d_{p}$ : 比表面積平均径 $(\mathrm{m})$

$a:$ 粘性抵抗係数

$b:$ 慣性抵抗係数

\section{文献}

1 ) 例えば E. W. Voice, S. H. Brooks and P. K. Gledhill: J. Iron Steel Inst., 174 (1953), p. 136

2 ) 吉永眞与, 久保敏彦: 住友金属, 29 (1977), p. 383

3 ) 柴田充蔵, 和島正己, 相馬英明, 松岡 宏: 鉄と鋼, 70 (1984), p. 178

4 ) E. Kasai, B. Batcaihan, Y. Omori, N. Sakamoto and A. Kumasaka: ISIJ Int., 31 (1991), p. 1286

5 ) 田口 勇, 中村滋男: 鉄と鋼, 71 (1985),p. 1685

6 ）田口 勇, 田中幸基: 鉄と鋼，72（1986), p. 1629

7 ) F. A. L. Dullien: Porous Media (1979), p. 90 [Academic Press]

8 ) T. Inazumi, S. Kasama, K. Sato, M. Sasaki and T. Tanaka: Proc. 5th Int. Symp. Agglomeration, Brighton, (1989), p. 559

9 ) 奥野嘉男, 川口卓也, 稲角忠弘: 学振 54 委-No. 1938 (平成 3 年 7 月) 